\title{
SUGGESTION IN CONTEXT: PSYCHOPATHOLOGY AS INVITED BEHAVIOUR ${ }^{\star}$
}

\section{David P Fourie}

Ph D

Professor, Dept of Psychology, University of South Africa

Correspondence: fouridp@unisa.ac.za

*An earlier version of this article was presented as an Invited Paper at the $3^{\text {rd }}$ International Symposium on Suggestion and Suggestibility, Munich, Germany, 2 -7 October 2000

Key words: "indirect" suggestion; suggestibility, context of meaning; co-construction; attributions of meaning

\begin{abstract}
Recent work has shown that suggestion is not a simple, unidirectional technique to influence people. It can best be understood as a multifaceted and recursive linguistic process which is contextual in nature. Using a social constructionist point of departure this article examines this verbal and non-verbal linguistic event and shows that suggestion occurs as a co-constructed context of invitation. The emergence of psychopathology is used to illustrate the process and the implications of this view for both psychological and medical treatment are highlighted.
\end{abstract}

\section{OPSOMMING}

Onlangse werk het aangedui dat suggestie nie 'n eenvoudige eenrigting-tegniek is om mense te beïnvloed nie. Dit kan ten beste verstaan word as ' $n$ veelvlakkige en rekursiewe linguistiese proses wat kontekstueel van aard is. Hierdie artikel ondersoek hierdie verbale en nie-verbale linguistiese gebeurtenis vanuit 'n sosiaal-konstruksionistiese vertrekpunt en wys hoe suggestie optree as 'n geko-konstrueerde konteks van uitnodiging. Die voorkoms van psigopatologie word gebruik om die proses te illustreer en die implikasies van hierdie siening vir sowel sielkundige as mediese behandeling word uitgelig. 


\section{INTRODUCTION}

Suggestion has been viewed traditionally as a unidirectional technique to influence people, an almost magical process wherein one person would indicate, verbally or otherwise, to another to act in a certain way and wherein the second person, depending on his/her level of suggestibility, would then act more or less involuntarily in the suggested way. This view has been widely adopted whether suggestion was considered in conjunction with hypnosis or not, even though suggestion is not confined to situations designated as hypnotic (Kirsch, 1997:212-225; Kirsch \& Braffman, 1999:224-230). Based on this conceptualisation, research focussed mainly on two aspects of suggestion, namely on the wording and/or presentation thereof and on the hypothesised suggestibility of subjects. The emergence of so-called "indirect" suggestion, as opposed to the more traditional "direct" forms of suggestion, was an outflow of the study of the presentation of suggestions, whereas the sustained interest in the measurement and enhancing of suggestibility reflected the second focus area.

Initially, when "indirect" suggestion was "discovered", it looked very promising. Barber (1977:138-147) obtained suggested analgesia in 99 out of 100 randomly selected dental patients by presenting "indirect" suggestions of comfort and relaxation to them immediately before surgery, never mentioning the word "pain". However, when this type of suggestion was investigated under better controlled (laboratory) circumstances, its promise faded, (for example, Van Gorp, Meyer \& Dunbar, 1985:319-328). It seemed to be about equally as effective as traditional, "direct" suggestion (under the same laboratory conditions) (Lynn, Neufeld \& Maré, 1993:124-152). In a similar vein in the second focus area, a wide variety of efforts to enhance suggestibility were not very successful, leading to the conclusion that suggestibility, as an individual trait or skill, was relatively stable (Piccione, Hilgard \& Zimbardo, 1989:289295).

These experiments and findings reflect the abovementioned conceptualisation of suggestion as a lineal, unidirectional process relatively independent of context. By focussing on the wording of suggestions and on the hypothesised suggestibility of the individual, researchers largely disregarded the circumstances in which the suggestion took place (Fourie, 1997:12551266). Precisely by comparing "direct" and "indirect" suggestions in the same (laboratory) situation, keeping the context invariate, the previously observed differences between them disappeared. Furthermore, precisely by carrying out pre-and post-testing of suggestibility within the same (laboratory) context before and after an intervening enhancement procedure, differences between pre- and post-testing scores largely disappeared, regardless of the nature of the intervening procedure. This means that the previously observed differences probably reflected differences in context, rather than intrinsic differences; a point made before (Fourie \& Lifschitz, 1988:166-177). It implies that context is important in the understanding of suggestion. More recent theoretical writings took cognisance of earlier concerns and emphasised this importance (for example, Gheorghiu \& Wallbott, 1995:117-140; Kruse, 1989:91-98; Peter, 1996:157-170).

Using a broadly social constructionist point of departure this article now aims to go a step further by showing that suggestion, as a verbal and non-verbal linguistic event, derives its meaning largely from the context in which it is seen to operate. In fact it proposes that the context itself is an inherent part of the particular suggestion. This perspective is illustrated by a case example showing how the life circumstances of clients form co-constructed contexts of meaning which could suggest, evoke or "invite" certain psychopathological behaviours. This has not been made explicit before and has implications for all treatment agents, whether in the medical, dental, nursing or psychological professions. All such agents have to deal in practice with these types of "invited" behaviours and cognisance of the way in which context, through suggestion, informs client or patient behaviours, opens different potential treatment strategies and modalities.

This is important, because many treatment agents tend to adopt a stance which, similar to that followed in research, seems to disregard context. One example of this is to be found in the routine application of suggestibility testing or hypnotic susceptibility testing prior to clinical work (see, for example, Sacerdote, 1982:354-376). The reductionist assumption here is that the clinician should know how suggestible the client is before suggestions are presented in treatment. However, this presumes that suggestibility is relatively stable and 
uninfluenced by the context, precisely that which is questioned above. Furthermore, such indiscriminate application of suggestibility testing makes as if the testing procedure and circumstances have no influence on the rest of the treatment. This is not the case. Testing defines the situation in a particular way (usually as "scientific", "objective" and "clinical") which in turn colours the subsequent treatment, potentially limiting the treatment possibilities.

Another example of the disregarding of context in clinical work is embodied by the widespread application of techniques or strategies merely because they are thought to be appropriate to the particular problem and without proper consideration of the specific attributional context in which they are to be applied. For example, almost all psychotherapy or psychopathology handbooks list techniques which can be used to treat various problems (for example, Bennett, 2003:3-442). Such an orientation implies that certain techniques can influence particular problems in a unidirectional way regardless of context. The focus here typically is on the particular technique and on the particular problem as if these were entities of some sort rather than human behaviours embedded in a specific attributional context. An anecdotal statement sometimes ascribed to Carl Whittaker illustrates the difference: "I don't know how to treat anorexia, but I do no how to handle a teenager who refuses to eat".

\section{CONTEXT OF SUGGESTION}

Whereas laboratory work in the two mentioned focus areas de-emphasised the context in which suggestions are embedded, and whereas, as we saw, clinical practice often followed suit, clinical writings in fact abound with case examples in which the role of the context can be hypothesised if not observed. This means that the suggestive role played by the context can often be seen in clinical examples, but this is not often emphasised in the presentation of the particular examples because the presentation is focussed on technique. Examples of this can be found inter alia in the literature on the currently popular technique of Eye Movement Desensitisation and Reprocessing (for example, De Jongh, Van den Oord \& Ten Broeke, 2002:1489-1503; Maxwell, 2003:281-293) wherein change was ascribed to the particular technique with little attention given to contextual elements.
The contextual role of suggestion came to the fore very forcefully in a case seen a while ago:

$\mathrm{Mr} \mathrm{X}$, a crusty old gentleman of 66 , brought his wife for hypnosis more or less against her will. He refused to let the therapist talk to her and insisted that he tell the story himself. He also refused to sit down, but stood talking uncomfortably close to the therapist claiming that he was a little hard of hearing. In this position he related that he had had a near accident a month before, but that God had saved him on condition that he went home and "put right that which is wrong". On returning home he had confronted his wife with a suspicion that she had had sexual intercourse with a friend of his on two occasions thirty years before. When she denied this, he insisted that she confess, not for his sake, because already at the time of the alleged occurrences he had decided not to mention his suspicion and to forgive her, but for the sake of her own relationship with God which he, as a very religious family man, saw as his responsibility. For a month he had been badgering her, but she had refused to confess to something she said she did not do. In the end he had convinced her to come for hypnosis so as to find out the "real" truth. In order to "protect" her, he did not want the therapist to talk to her, only to hypnotise her.

This interpersonal context embodied a potential trap for the therapist: To do as $\mathrm{Mr} \mathrm{X}$ requested, was implicitly to side with him in his conflict with his wife. But to refuse was to run the real risk of alienating $\mathrm{Mr} X$ and therefore not to be of help in solving the problem. Instead, the therapist humbly asked permission from $\mathrm{Mr} \mathrm{X}$ to be allowed to go aside and pray for guidance about this difficult problem. Given the context of professed religiosity and concern for Mrs $\mathrm{X}, \mathrm{Mr} \mathrm{X}$ could hardly refuse this request. The therapist then returned, brought Mrs X into the therapy room and said that he had "received a message from God" for $\mathrm{Mr} \mathrm{X}$. The message was for $\mathrm{Mr} X$ to search his conscience and then to give both the therapist and Mrs $X$ a solemn undertaking before God that he would accept whatever "truth" were to come from the hypnosis. If he insisted on "proving" his suspicion and was not open to the possibility that the suspicion could be unfounded, then he should be honest enough to admit it and then hypnosis would be of no help. Again $\mathrm{Mr} \mathrm{X}$ was in a position where he could not refuse to give such an undertaking because that would have shown that his 
religiousness and his professed concern for the spiritual welfare of his wife were false. When, as was expected, the subsequent hypnosis revealed nothing but further tearful denials from the wife, then the therapist could and did insist that $\mathrm{Mr} \mathrm{X}$ comply with his given undertaking and leave her in peace.

In this case the therapist avoided the potential trap by utilising the context of religiousness in such a way as to interrupt the vicious cycle of accusations and denial in which the couple had become embroiled. A number of suggestions to Mr X could be identified here:

- $\quad$ To make as if the therapist were as religious as he himself.

- $\quad$ To take responsibility for his suspicion and not to put all the responsibility on his wife (and on God and/or the therapist).

- To honour his "undertaking" no matter what the outcome of the hypnosis.

All of these suggestions derived their meaning from $\mathrm{Mr}$ $X$ 's professed religious beliefs. Not one of them would have made any sense in a context devoid of this central theme. Note that, had the therapist allowed his own feeling of discomfort (an implicit suggestion from $\mathrm{Mr} \mathrm{X}$ ) flowing from the awkwardly close physical distance imposed on him, to determine his actions, he might have done something probably less effective, such as to confront $\mathrm{Mr} \mathrm{X}$ with his inappropriate behaviour.

This case description illustrates that suggestions are meaningless out of context. To teach student therapists, for instance, to suggest to clients that they allow their therapist to go aside and pray, is ridiculous. Only in the particular context did the particular suggestions have meaning and therefore effect. "Messages from God" would be laughable to less fanatically religious clients. But in the particular context the client could not openly defy such a message, even if he wanted to, without putting his professed religiousness into question.

It is clear therefore that the context in which suggestions are offered is extremely important in that suggestions derive their meaning at least partly from this context.

\section{SUGGESTION AS CONTEXT: PSYCHOPA- THOLOGY AS INVITED BEHAVIOUR}

However, it goes much further than that. The context itself embodies interlinked meanings which can be seen to function as suggestions in equally interlinked ways. Consider the following case in which marital therapy was requested:

John and Caroline (pseudonyms) were both in their late twenties. They had been married for three years and had no children. Before the marriage their relationship had broken up for some months and in this time John had had a brief relationship with another woman. Although Caroline had later forgiven him for this (after all, as far as he was concerned at the time, their relationship was over), she was extremely jealous of him and was convinced that he would leave her at some stage. This had now come to a head because John had become friendly with a female colleague at work. Although John denied a romantic interest in this person, Caroline was convinced that he did have such an interest and was unfaithful to their marriage. Not only did this lead to considerable friction between them, but to the re-emergence of the anorexia from which Caroline had suffered in the past and which she thought she had overcome.

Until her marriage Caroline had never been alone since before her birth her identical twin sister was always there. This sister, according to Caroline, was their father's favourite. The sister was an achiever, the capable, responsible one of the two who also took the initiative in their relationship. Caroline felt protected, but also overshadowed by her sister. Even though Caroline described herself as a perfectionist, nothing she did was ever seen as quite as good as the sister's achievements. When they both went on a diet, the sister became slim, while Caroline became anorexic, thereby playing into the family's attributions of meaning about her, namely that she was highly strung and "could never let go", in short, that something was wrong with her.

Caroline therefore seemed to have grown up in a context which suggested that despite all her frantic efforts she was not quite good enough. The family context simultaneously suggested that Caroline should attempt to be better and that she should fail in this quest. By constantly trying to be perfect, and failing, she not only responded to both elements of this suggestion, but also confirmed the family's attributions of meaning underlying it. This double action of continuous trying, but failing, 
was previously called the "conservation of ambivalence" (Fourie, 1996:53-70, Fourie, 2003:51-59). Everybody in the family can be said to have contributed in their different ways to this conservation of ambivalence around Caroline. For example, by being capable and successful the twin sister constantly set the standard against which Caroline was evaluated by herself and by the other members of the family. The symptom of anorexia fitted perfectly within this contextual pattern of interlinked meanings and expectations: dieting became so successful that it was a failure. One could say that the context which continually suggested to Caroline to try, but to fail, "invited" behaviour such as anorexia, especially at a time when the twins, as teenagers, started to become concerned about their appearance.

It is interesting to note further that, when Caroline got engaged to be married, she "overcame" the anorexia. The twin sister had not as yet found a prospective husband at that stage, so that for once Caroline had achieved more than the sister. However, by showing her jealousy about the relationship in which John became involved when they had broken up, Caroline brought him into the family suggestive context so that he too began to expect extreme behaviour from her. This eventually "infected" their marital relationship with the same attribution of meaning, namely that Caroline was viewed as not quite good enough. In turn this probably underlay John's interest in his female colleague, which meant only one thing to Caroline, namely further competition. And the suggestion from the context, as always, was that in competition Caroline had to come second.

In this way the family's suggestive context which "invited" ambivalent behaviour from Caroline, was recreated in her marriage so that the marital context came to "invite" similar behaviour, in this case the return of anorexia. This is fitting, because again Caroline was competing with another woman in terms of her female attractiveness. Even the larger, cultural context can thus be said to help "invite" Caroline to attempt to improve her appearance (but to fail).

Without cognisance of this context of suggestion treatment efforts might very well fail. Marital therapy aimed at improving the couple's communication skills and/or interaction, for instance, would imply ignoring or discounting of the wider suggestive context in which the marital problems can be seen to be embedded. This would amount to what Watzlawick, Weakland and Fisch (1974:40-46) called a "terrible simplification" and would be unlikely to be successful. Similarly it is unlikely that pure medical treatment of the anorexia would be of much value (see, for example, Limacher, Dahler, Bösch \& Egli, 1991:65-68). Whatever treatment agent(s) would therefore be involved in this or any other case, in order to improve their chances of success they would have to let themselves be informed by the wider context of suggestion. The question they should ask themselves, then, would not be what technique would resolve the particular problem - a question which reflects lineal and reductionist thinking - but in what way(s) they can intervene in the specific suggestive context to invite the people involved to think and act differently.

\section{CONCLUSION}

It becomes clear then that the way in which system members think about themselves and about each other entails a co-constructed, multifaceted and recursive linguistic process which embodies unwitting suggestions to behave in one way or the other. As could be seen from the situation of John and Caroline this contextual process of suggestion is complicated, with different ideas and attributions of meaning interlinking to form a coherent whole which then "invites" certain behaviours from certain people. Lundh (1998:24-38) calls this a "certain suggestive climate" which develops in time in a specific social context.

This view of suggestion implies that treatment becomes equally complicated. It can no longer be seen as a simple lineal application of a technique or suggestion to a problem. Instead, it is a creative linguistic interweaving into the threads of the wider suggestive context in order to perturb the ever-changing pattern of the client's or family's life in a direction mutually defined as positive. In similar vein but with a slightly different focus Otani (1991:111-121) speaks about the "decontextualising" of disfunctional contexts in therapy, meaning suggestive intervention to disrupt these disfunctional ideas and attributions. Seen in this way suggestion becomes something very different from the traditional wishing away of symptoms.

\section{ACKNOWLEDGEMENT}


Grants received by the National Research Foundation, Division for Social Sciences and Humanities, and by the University of South Africa are gratefully acknowledged.

\section{REFERENCES}

BARBER, J 1977: Rapid induction analgesia: A clinical report. American Journal of Clinical Hypnosis, 19(3):138-147. BENNETT, P 2003: Abnormal and clinical psychology. An introductory textbook. Philadelphia: Open University Press.

DE JONGH, A; VAN DEN OORD, H \& TEN BROEKE, E 2002: Efficacy of eye movement desensitization and reprocessing in the treatment of specific phobias: Four single-case studies on dental phobia. Journal of Clinical Psychology, 58(12):1489-1503. FOURIE, DP 1996: Being stuck: Somatic symptoms and the conservation of ambivalence. Journal of Family Psychotherapy, 7(2):53-70.

FOURIE, DP 1997: "Indirect" suggestion in hypnosis: Theoretical and experimental issues. Psychological Reports, 80:1255-1266. FOURIE, DP 2003: Limited options: Symptoms as expressions of ambivalence. American Journal of Family Therapy, 31(1):5159.

FOURIE, DP \& LIFSCHITZ, S 1988: Not seeing the wood for the trees: Implications of susceptibility testing. American Journal of Clinical Hypnosis, 30(3):166-177.

GHEORGHIU, VA \& WALLBOTT, HG 1995: Suggestion and attribution of meaning: A cognitive and social-psychological perspective. Comunicazioni Scientifiche di Psicologia Generale, 12:117140.

KIRSCH, I 1997: Suggestibility or hypnosis: What do our scales really measure? International Journal of Clinical and Experimental Hypnosis, 45(2):212-225.

KIRSCH, I \& BRAFFMAN, W 1999: Correlates of hypnotizability: The first empirical study. Contemporary Hypnosis, 4(2):224230.

KRUSE, P 1989: Some suggestions about suggestion and hypnosis: A radical constructivist view. (In: Gheorghiu, VA; Netter, P; Eysenck, HJ \& Rosenthal, R eds. 1989: Suggestion and suggestibility: Theory and research. Berlin: Springer, pp 91-98.)

LIMACHER, B; DAHLER, E; BÖSCH, J \& EGLI, N 1991: Color me multi-colored: A note on problems in clinical research methodology. Family Systems Medicine, 9(1):65-68.

LUNDH, L-G 1998: Normal suggestion. An analysis of the phenomenon and its role in psychotherapy. Clinical Psychology \& Psychotherapy, 5(1):24-38.

LYNN, SJ; NEUFELD, V \& MARÉ, C 1993: Direct versus indirect suggestions: A conceptual and methodological review. International Journal of Clinical and Experimental Hypnosis,
41(1):124-52.

MAXWELL, J 2003: The imprint of childhood physical and emotional abuse: A case study on the use of EMDR to address anxiety and a lack of self-esteem. Journal of Family Violence, 18(5):281293.

OTANI, A 1991: Contextual roles in clinical hypnosis and hypnotherapy: Theory and applications. American Journal of Clinical Hypnosis, 34(2):111-121.

PETER, B 1996: Normal instruction or hypnotic suggestion: What makes the difference? Hypnosis International Monographs, 2:157-170.

PICCIONE, C; HILGARD, ER \& ZIMBARDO, PG 1989: On the degree of stability of measured hypnotizability over a 25 -year period. Journal of Personality and Social Psychology, 56(2):289295.

SACERDOTE, P 1982: A nonstatistical dissertation about hypnotizability scales and clinical goals: Comparison with individualized induction and deepening procedures. International Journal of Clinical and Experimental Hypnosis, 30(4):354376.

VAN GORP, WG; MEYER, RG \& DUNBAR, KD 1985: The efficacy of direct versus indirect hypnotic induction techniques on reduction of experimental pain. International Journal of Clinical and Experimental Hypnosis, 33(4):319-328.

WATZLAWICK, P; WEAKLAND, J \& FISCH, R 1974: Change: principles of problem formation and problem resolution. New York: Norton. 